\title{
BENTUK PERLINDUNGAN HUKUM TERHADAP KEKAYAAN MINYAK DAN GAS BUMI SEBAGAI ASET NEGARA MELALUI INSTRUMEN KONTRAK
}

\author{
Faizal Kurniawan \\ Fakultas Hukum Universitas Airlangga Surabaya \\ e-mail:faizal@fh.unair.ac.id
}

\begin{abstract}
ABSTRAK
Negara mempunyai kekuasaan untuk mengelola sumber daya alam demi mewujudkan keadilan sosial, kesejahteraan umum dan untuk kemakmuran rakyat. Instrumen hukum kontrak menjadi payung hukum sebagai upaya perlindungan hukum terhadap aset negara yang berupa minyak dan gas bumi. Kontrak Bagi Hasil menjadi pilar dasar dalam upaya pengelolaan dan pemanfaatan kegiatan usaha minyak dan gas bumi. Kontrak Bagi Hasil merupakan kontrak publik yang tidak sepenuhnya tunduk pada hukum privat. Dalam melakukan hubungan kontraktualnya, negara tidak boleh dirugikan (imunitas negara) dan harus memperhatikan klausula-klausula yang menitikberatkan pada perlindungan aset negara.

Kata Kunci: kontrak bagi hasil, kontrak publik, imunitas negara, klausula perlindungan aset negara.

ABSTRACT

State has the power to manage natural resources for the sake of social justice, the general welfare and are used as much as possible the greatest benefit for the greatest welfare of people. Contract law is the main instrument used to protect the state assets including oil and gas. Production Sharing Contract as a legal safeguard for oil and gas, is a fundamental pillar in the effort and utilization management activities of oil and gas. In this Production Sharing Contract, which the contracts also involve the government and called government contract, has a unique characteristic which is not entirely subject to private law. In principle, the state should not be harmed, called as state immunity. This principle also applies universally in the interest of protecting the state assets.
\end{abstract}

Keywords: production sharing contract, government contract, state immunity, protection of state assets clause.

\section{PENDAHULUAN}

Sumber kekayaan alam Indonesia yang sangat strategis dan juga memiliki peranan penting terhadap perekonomian nasional antara lain adalah sumber daya alam berupa minyak dan gas bumi yang harus dipergunakan sebesar-besarnya untuk kemakmuran rakyat Indonesia. Hal ini ditegaskan dalam Pasal 33 ayat 3 Undang-Undang Dasar RI 1945 (yang selanjutnya disebut UUD 1945) yang menyatakan bahwa bumi, air dan kekayaan alam yang terkandung didalamnya dikuasai oleh negara dan dipergunakan untuk sebesar-besarnya kemakmuran rakyat. Dalam hal ini pemerintah yang diberikan kewenangan oleh negara dalam bentuk Kuasa Pertambangan untuk menyelenggarakan kegiatan eksplorasi dan eksploitasi minyak dan gas bumi.
Menurut Undang-Undang No. 22 Tahun 2001 tentang Minyak dan Gas Bumi (yang selanjutnya disingkat UU Migas) eksplorasi merupakan kegiatan yang dilakukan dalam rangka memperoleh informasi mengenai kondisi geologi untuk menemukan dan memperoleh perkiraan cadangan minyak dan gas bumi. Ditegaskan pula dalam undang-undang ini bahwa eksploitasi merupakan rangkaian kegiatan yang bertujuan menghasilkan minyak dan gas bumi yang terdiri atas kegiatan pengeboran dan penyelesaian sumur, pembangunan terhadap sarana pengangkutan, penyimpanan, juga pengolahan untuk pemisahan dan pemurnian minyak dan gas bumi di lapangan serta kegiatan lain yang dapat menjadi pendukung pelaksanaannya. 
Pengelolaan sumber daya alam ini diharapkan secara maksimal dapat memberikan kesejahteraan dan juga kemakmuran rakyat, sehingga kegiatan pengelolaannya sangatlah penting untuk dilaksanakan dengan baik. Salah satu instrumen hukum atau sarana terpenting yang dapat digunakan adalah kontrak, khususnya Kontrak Bagi Hasil atau disebut juga Production Sharing Contract. Kontrak Bagi Hasil atau Production Sharing Contract ini merupakan sarana yang spesifik ditujukan untuk dapat mengatasi permasalahan-permasalahan dalam eksplorasi dan eksploitasi terhadap pertambangan minyak dan gas bumi. Permasalahan tersebut antara lain dalam hal terdapat keterbatasan modal, teknologi, dan sumber daya manusia. Kontrak ini dilakukan sebagai salah satu kontrak kerjasama yang dilaksanakan dalam rangka untuk memberikan perlindungan terhadap aset negara serta memberikan keuntungan bagi negara. Kontrak kerjasama ini dilakukan antara pemerintah dengan kontraktor yang merupakan Badan Usaha dan Bentuk Usaha Tetap, dalam perkembangannya, kontrak kerjasama ini menjadi hal krusial karena disebabkan oleh banyaknya pihak yang memiliki kepentingan terhadap minyak dan gas bumi sehingga hal ini kemudian memunculkan urgensi perlindungan aset negara dalam pengelolaan migas.

Berdasar latar belakang permasalahan tersebut di atas, maka masalah penelitian dirumuskan: Pertama, Bentuk perlindungan hukum terhadap aset negara terkait dengan pengelolaan minyak dan gas bumi; Kedua, Klausula-klausula sebagai upaya preventif perlindungan aset negara dalam Kontrak Bagi Hasil (Production sharing contract).

\section{PEMBAHASAN}

Kontrak Bagi Hasil (Production Sharing Contract) ini merupakan kontrak kerjasama dalam kegiatan eksplorasi dan eksploitasi yang lebih menguntungkan negara dan hasilnya dipergunakan untuk sebesarbesarnya kemakmuran rakyat. Kontrak Bagi Hasil ini melibatkan pemerintah selaku kontraktan. Kontrak yang melibatkan penguasa sebagai pihak ini, lazim disebut sebagai government contract. Yohanes Sogar Simamora menterjemahkan istilah tersebut dengan kontrak pemerintah (Y. Sogar Simamora, 2009:55).

Saat pemerintah memasuki hubungan kontraktual dalam skala privat, pemerintah mempunyai peran yang ganda (double role). Di satu sisi, pemerintah mempunyai kedudukan seperti subjek privat lain, tetapi di sisi lain kedudukannya adalah badan publik yang tidak terlepaskan. Ketika pemerintah menjalin perikatan dalam skala privat maka sejak itu harus dinilai pemerintah menyatakan tunduk pada aturan privat. Dalam situasi ini maka berlakulah segala konsekuensi hukum yang timbul akibat hubungan yang dibentuk itu yaitu konsekuensi akan berlakunya prinsip dan aturan hukum dalam lapangan Hukum Perdata baik yang bersifat materiil maupun formil (Y. Sogar Simamora, 2009:93). Sehingga pada dasarnya pemerintah tidak kebal dan dapat digugat.

\section{Prinsip, Fungsi dan juga Kewenangan Negara dalam Pengelolaan Minyak dan Gas Bumi sebagai Kekayaan Alam yang Dikuasai Negara}

Kekuasaan negara atas sumber daya alamnya, akan melahirkan penguasaan negara dimana hak penguasaan tersebut diantaranya kewenangan untuk mengatur, mengawasi, dan mengurus segala bentuk pengusahaan dan pengelolaan kekayaan alam, serta mempunyai tanggungjawab untuk dipergunakan dan ditujukan bagi sebesar-besarnya kesejahteraan dan kemakmuran rakyat, sebagaimana mandat Pasal 33 UUD 1945.

Kewenangan yang melekat pada negara, yang dalam hal ini dilakukan oleh pemerintah, merupakan suatu kewenangan yang diberikan oleh UUD 1945 melalui UU Migas sebagai derivasinya dengan tujuan mewujudkan keadilan sosial, kesejahteraan umum dan dipergunakan sebesar-besarnya untuk kemakmuran rakyat (Y. Sogar Simamora, 2009:18-19).

Atas dasar hubungan Hak Penguasaan Negara dengan objeknya kepemilikan atau juga merupakan objek Hak Penguasaan Negara, maka Hak Penguasaan Negara harus dilihat dalam konteks hak dan kewajiban negara sebagai pemilik (domein) yang mana bersifat publiekrechtelijk, bukan sebagai eignaar yang bersifat privaaterechttelijk (Y. Sogar Simamora, 2009:33). Status kepemilikan yang diperoleh pemerintah atas Migas dinyatakan dalam ketentuan Pasal 6 UU Migas ayat 2 huruf a (wewenang atributif) yakni kepemilikan sumber daya alam tetap di tangan pemerintah sampai pada titik penyerahan.

Namun, Hak Penguasaan Negara itu sendiri juga mempunyai sifat dari segi privat, yakni pada saat terjadinya suatu hubungan hukum di antara negara sebagai badan hukum publik dengan pihak badan hukum perdata, swasta (Badan Usaha Milik Negara, Badan Usaha Milik Daerah, Koperasi, Perusahaan atau Badan Usaha Asing, dan Penanaman Modal Asing) dalam hal pengusahaan migas dari mulai kegiatan hulu sampai kegiatan hilir. Hal ini terjadi tatkala negara, yang dikuasakan kepada pemerintah menjalankan fungsi mengurus objek kekayaan alam, yang mana dilandaskan dalam bentuk perjanjian kerja 
sama. Dalam keadaan yang demikian ini, penguasa negara atau pemerintah menurut Kranenburg dan Vegting bertindak sebagai organ dari badan publik yang berupa private rechtpersoonlijkeheid (Y. Sogar Simamora, 2009:58). Negara sebagai subjek hukum memiliki kekayaan yang dimilikinya dalam posisi sebagai majikan dan badan hukum perdata sebagai pemborong atau pembeli (Y. Sogar Simamora, 2009: 58). Hal ini dilakukan karena peranan negara disini sebagai pemegang kekuasaan, maka berwenanglah untuk memberikan kuasa kepada badan usaha atau perorangan untuk melakukan pengusahaan atau juga pengelolaan atas bahan galian yang ada dalam wilayah hukum pertambangan Indonesia (Y. Sogar Simamora, 2009:58). Hal ini ditegaskan dalam ketentuan Pasal 4 UU Migas, bahwa: Minyak dan Gas Bumi sumber daya alam strategis tak terbarukan yang terkandung di dalam wilayah hukum pertambangan Indonesia merupakan kekayaan nasional yang dikuasai oleh negara; Penguasaan diselenggarakan oleh pemerintah sebagai pemegang kuasa pertambangan; dan juga Pemerintah sebagai pemegang kuasa pertambangan membentuk Badan Pelaksana.

\section{Kewenangan Kementerian Energi dan Sumber Daya Mineral}

Dalam Pasal 4 UUD 1945, menyatakan bahwa Presiden memegang Kekuasaan pemerintahan dan dalam Pasal 17 menyatakan bahwa presiden dalam menjalankan roda pemerintahan dibantu oleh menterimenteri negara yang mana membidangi urusan-urusan tertentu pemerintahan, yang salah satunya itu ialah Menteri Energi dan Sumber Daya Mineral (yang selanjutnya disebut ESDM).

Fungsi, kewenangan, yang melekat pada Menteri ESDM dinyatakan dalam Pasal 12 UU Migas antara lain: 1. Wilayah kerja yang akan ditawarkan kepada badan usaha atau bentuk usaha tetap ditetapkan oleh menteri setelah berkonsultasi dengan pemerintah daerah; 2. Penawaran wilayah kerja sebagaimana dimaksud dalam ayat 1 dilakukan oleh menteri; 3 . Menteri menetapkan badan usaha atau bentuk usaha tetap yang diberi wewenang melakukan kegiatan usaha eksplorasi dan eksploitasi pada wilayah kerja sebagaimana dimaksud dalam ayat 2 .

Pada tahun 2003 Mahkamah Konstitusi (yang selanjutnya disebut MK) telah mengeluarkan suatu keputusan yang menyatakan Pasal 12, khususnya ayat 3, itu dianggap bertentangan dengan Pasal 33 UUD 1945 dalam Putusan MK No. 002/PUU-I/2003 tentang Uji Materi UU Migas terhadap UUD 1945. Putusan MK dapat diterjemahkan bahwa kata-kata 'diberi wewenang' itu mengandung artian bahwa menteri dengan berdasarkan undang-undang dapat memberikan kewenangan publik yang ada padanya kepada Badan Usaha atau Bentuk Usaha Tetap (Didik S. Setyadi, 2007:36).

Secara lebih khusus wewenang menteri dalam halhal tertentu yang lebih bersifat teknis dalam bidang pembinaan dan pengawasan kegiatan eksplorasi dan eksploitasi migas yang dimandatkan kepada Direktur Jenderal Migas yang memimpin Ditjen Migas (Didik S. Setyadi, 2007:33). Dalam melaksanakan fungsi, Menteri ESDM atau juga Direktorat Jenderal Migas berwenang mengeluarkan berbagai perizinan terkait kegiaan eksplorasi dan eksploitasi, dengan demikian fungsi yang dijalankan sebagai Administrasi Negara sangat menonjol karena kewenangan tersebut (Didik S. Setyadi, 2007:33).

Dalam Pasal 4 Peraturan Pemerintah No. 35 Tahun 2004 tentang Kegiatan Hulu Minyak dan Gas Bumi (selanjutnya disingkat PP No. 35 Tahun 2004) jo. Peraturan Pemerintah No. 34 Tahun 2005 tentang Perubahan atas PP No. 35 Tahun 2004 (selanjutnya disingkat PP No. 34 Tahun 2005), bahwa Menteri dalam menetapkan kebijakan Penawaran Wilayah Kerja itu haruslah berdasarkan pada pertimbangan yang teknis, ekonomis, tingkat resiko, efisiensi, dan berazaskan keterbukaan, keadilan, akuntabilitas, dan juga persaingan.

\section{Kewenangan Menteri ESDM dalam Pelaksanaan Kegiatan Hulu Migas}

Kewenangan Menteri ESDM dalam pelaksanaan kegiatan hulu migas pada dasarnya ditujukan untuk terciptanya suatu Kontrak Kerja Sama (selanjutnya disingkat KKS) sebagaimana dinyatakan dalam Pasal 24 PP No. 35 Tahun 2004 jo. PP No. 34 Tahun 2005, bahwa kegiatan usaha hulu dilaksanakan oleh Badan Usaha atau Bentuk Usaha Tetap berdasarkan KKS dengan Satuan Kerja Khusus Migas (selanjutnya disingkat SKK Migas). Meskipun KKS itu dilakukan antara kontraktor dengan SKK Migas bukan berarti menteri tidak mempunyai kewenangan dalam proses kegiatan tersebut, justru kewenangan menteri disini sangat vital dalam hal menetapkan bentuk-bentuk dan ketentuan pokok Kontrak Kerja Sama setelah mendapatkan pertimbangan Kepala SKK Migas.

Menteri juga berwenang memberikan persetujuan atas permohonan oleh kontraktor migas mengenai perpanjangan akan jangka waktu yang dimiliki KKS, pengalihan, pemindahtanganan, dan juga penyerahan sebagian atau seluruh hak dan kewajiban yang melekat padanya (participating interest). 


\section{Kedudukan dan Kewenangan SKK Migas sebagai Pengganti BP Migas}

Keberadaan akan SKK Migas di dalam percaturan dunia migas di Indonesia merupakan hal yang baru. Kedudukan hukum SKK Migas berdasarkan Peraturan Presiden No. 95 Tahun 2012 tentang Pengalihan Pelaksanaan Tugas dan Fungsi Kegiatan Usaha Hulu Minyak dan Gas Bumi (selanjutnya disingkat Perpres No. 95 Tahun 2012) dan Peraturan Presiden No. 9 Tahun 2013 tentang Penyelenggaraan Pengelolaan Kegiatan Usaha Hulu Minyak dan juga Gas Bumi (selanjutnya disingkat Perpres No. 9 Tahun 2013) adalah untuk menggantikan peran Badan Pelaksana Migas (selanjutnya disingkat BP Migas) dalam hal melaksanakan fungsi pengendalian dan pengawasan kegiatan usaha hulu di bidang migas.

Secara keseluruhan MK membatalkan Pasal 1 angka 23, Pasal 4 ayat 3, Pasal 41 ayat 2, Pasal 44, Pasal 45, Pasal 48 1, Pasal 59 huruf a, Pasal 61, Pasal 63 UU Migas. MK juga membatalkan frasa 'dengan Badan Pelaksana' dalam Pasal 11 ayat 1, frasa 'melalui Badan Pelaksana' di dalam Pasal 20 ayat 3, frasa 'berdasarkan pertimbangan dari Badan Pelaksana dan' dalam Pasal 21 ayat 1, frasa 'Badan Pelaksana dan' dalam Pasal 49 UU Migas. Seluruh Pasal tersebut oleh MK dinilai bertentangan dengan Pasal 33 UUD 1945.

Sesuai dalam putusan MK No. 36/PUU-X/2012, BP Migas dibubarkan oleh MK dikarenakan menurut pertimbangan MK, BP Migas hanya memiliki fungsi pengendalian dan juga pengawasan atas pengelolaan migas, namun tidak melakukan pengelolaan secara langsung (http://www.hukumonline.com/berita/baca/ 1t50a2367d37e5c/mk--bp-migas-inskonstitusional). Konsekuensinya adalah model hubungan antara BP Migas sebagai representasi negara dengan Badan Usaha dan Badan Usaha Tetap dalam pengelolaan migas mendegradasi akan makna dari penguasaan negara atas sumber daya alam migas, dan dengan demikian maka bertentangan dengan aturan Pasal 33 UUD 1945 (www.hukumonline.com/berita/baca/ 1t50a2367d37e5c/mk--bp-migas-inskonstitusional). Artinya, konstruksi penguasaan migas melalui BP Migas, negara kehilangan kewenangannya untuk melakukan pengelolaan atau untuk menunjuk secara langsung BUMN untuk kemudian mengelola migas sesuai dengan maksud Pasal 33 UUD 1945.

Menindaklanjuti atas Putusan MK tersebut, maka dibuatlah Perpres No. 95 Tahun 2012 dan Perpres No. 9 Tahun 2013 untuk mengisi kekosongan hukum dan mengeliminir ketidakpastian hukum yang berpotensi muncul dalam pelaksanaan industri hulu migas yang tertuang dalam KKS paska dibubarkannya BP Migas. Hanya saja kedudukan SKK Migas bukanlah sebagai Badan Hukum Milik Negara (BHMN) seperti BP Migas akan tetapi menjadi unit satuan kerja di bawah menteri (cq. Menteri ESDM).

Salah satu isi dari putusan MK menyatakan bahwa 'Segala hak serta kewenangan BP Migas dalam KKS setelah putusan ini, dilaksanakan oleh Pemerintah atau Badan Usaha Milik Negara yang ditetapkan oleh Pemerintah.' Salah satu isi putusan tersebut kemudian ditindaklanjuti dalam Pasal 1 Perpres No. 95 Tahun 2012 bahwa pelaksanaan tugas, fungsi, dan organisasi Badan Pelaksana Kegiatan Usaha Hulu Minyak dan Gas Bumi dialihkan kepada menteri yang menyelenggarakan urusan pemerintahan di bidang minyak dan gas bumi, sampai dengan diterbitkannya peraturan yang baru dan Pasal 1 Perpres No. 9 Tahun 2013 bahwa menteri yang menyelenggarakan urusan pemerintahan di bidang energi dan juga sumber daya mineral, yang untuk selanjutnya disebut Menteri, membina, mengkoordinasikan dan juga mengawasi penyelenggaraan pengelolaan kegiatan usaha hulu minyak dan gas bumi. Dari kedua peraturan tersebut, jelas bahwa Pemerintah lebih memilih opsi yang diberikan oleh putusan MK terkait pembubaran BP Migas untuk melimpahkan tugas dan wewenang BP Migas kepada menteri yang membawahi langsung bidang migas daripada Badan Usaha Milik Negara.

Kemudian Pasal 3 Perpres No. 95 Tahun 2012 juga menegaskan bahwa seluruh proses pengelolaan kegiatan usaha hulu minyak dan gas bumi yang sedang ditangani oleh Badan Pelaksana Kegiatan Usaha Hulu Minyak dan Gas Bumi, dilanjutkan oleh menteri yang menyelenggarakan urusan pemerintahan di bidang minyak dan juga gas bumi sesuai dengan ketentuan peraturan perundang-undangan.

Berdasarkan pada uraian tersebut, maka segala hak dan kewajiban yang melekat pada BP Migas baik karena undang-undang maupun KKS beralih ke dan diemban oleh SKK Migas sebagai unit satuan di bawah Menteri ESDM sebagai suatu subjek kontrak (konraktan) pengganti dalam KKS. Meski BP Migas adalah pihak yang sebelumnya menandatangani setiap KKS, akan tetapi dengan bubarnya BP Migas yang berarti syarat sahnya perjanjian pada Pasal 1320 BW tidak terpenuhi dengan tidak adanya salah satu pihak, tidak secara otomatis setiap KKS menjadi tidak sah atau batal demi hukum. Mengingat terdapat sekian banyak KKS-KKS yang ada, adalah tidak mungkin bagi Pemerintah untuk tidak melindungi kepentingan para investor migas dan triliunan modal yang telah ditanam tersebut. Mengenai problematika 
tersebut pada Pasal 2 Perpres No. 95 Tahun 2012, menegaskan bahwa Segala Kontrak Kerja Sama yang ditandatangani antara Badan Pelaksana Kegiatan Usaha Hulu Minyak dan Gas Bumi dengan Badan Usaha atau Bentuk Usaha Tetap, tetap berlaku sampai masa berlakunya berakhir.

Seperti yang telah diuraikan sebelumnya, KKS merupakan suatu jenis kontrak yang unik yaitu pada satu sisi bermuatan hukum privat dan di sisi lain bermuatan hukum publik. Apa yang terkandung dalam kontrak pemerintah pada dasarnya adalah kemauan sepihak dari pemerintah. Syarat-syarat dalam kontrak telah disiapkan secara sepihak oleh pemerintah. Pihak kontraktor migas hanya mempunyai dua pilihan, setuju atau tidak. Sama sekali tertutup kemungkinan melakukan penawaran balik.

Eksistensi KKS itu bersumber dari UU Migas, termasuk juga di dalamnya pihak BP Migas sebagai rekan kontrak kontraktor migas. Oleh putusan MK yang membatalkan beberapa pasal dalam UU Migas mengenai eksistensi dan kedudukan BP Migas sebagai konsekuensi logisnya adalah akan dibubarkannya BP Migas. Apabila diperhatikan kini mengenai alur logika hukum dari eksistensi KKS tersebut, maka dapatlah dipastikan perubahan entitas kelembagaan dari pihak pemerintah tidak berpengaruh terhadap jalannya KKS dan juga otomatis tidak memerlukan adanya kesepakatan dengan para kontraktor migas terkait dengan kedudukan pemerintah disamping memposisikan sebagai entitas privat juga sebagai entitas publik yang tentunya ada sifat-sifat publik beserta segala proses perubahan yuridis-publik beserta konsekuensi hukum yang muncul yang melekat pada kedudukan pemerintah tersebut.

Seperti halnya BP Migas sebelumnya, keberadaan SKK Migas sebagai penerus BP Migas dalam skema KKS kegiatan hulu migas tetap tidak menganut skema perjanjian "B to B" (Business to Business) tetapi " $B$ to G" (Business to Government). Hal ini dikarenakan setiap hak dan kewajiban yang melekat pada BP Migas beralih kepada SKK Migas dan dengan demikian konsekuensi hukumnya pun sama meskipun secara kelembagaan telah berbeda.

Berdasarkan uraian-uraian sebelumnya, maka dengan tegas dapatlah dikatakan bahwa tugas dan kewenangan yang ada pada BP Migas juga sekaligus merupakan tugas dan kewenangan SKK Migas. Dan berikut adalah kewenangan BP Migas yang saat ini dilaksanakan oleh SKK Migas. Dalam Pasal 12 PP No. 42 Tahun 2002 jo. Pasal 1 Perpres No. 95 Tahun 2012 jo. Pasal 1 dan Pasal 2 ayat 1 Perpres No. 9 Tahun 2013, SKK Migas memiliki kewenangan, antara lain meliputi: Membina suatu kerjasama dalam rangka terwujudnya integrasi dan sikronisasi kegiatan operasional kontraktor KKS; Merumuskan kebijakan atau anggaran dan program kerja kontraktor KKS; Mengawasi kegiatan utama operasional kontraktor KKS; Membina seluruh aset kontraktor KKS yang menjadi milik negara; dan Melakukan koordinasi dengan pihak dan atau instansi terkait yang diperlukan dalam pelaksanaan kegiatan usaha hulu migas.

Tujuan terpenting di dalam fungsi pengawasan dan pengendalian yang dilakukan oleh SKK Migas adalah pengawasan dan pengendalian untuk (Didik S. Setyadi, 2007:39): Optimalisasi penerimaan negara; Pengendalian pembelanjaan untuk kegiatan eksplorasi dan eksploitasi yang dikemudian hari setelah kegiatan tersebut berproduksi harus diganti atau dikembalikan oleh pemerintah dari bagi hasil produksi migas yang lazim disebut dengan istilah Cost Recovery.

Salah satu tugas utama dalam hal pengendalian dan pengawasan yang dilakukan SKK Migas adalah memberikan persetujuan rencana kerja dan anggaran (WP\&B dan AFE) semua kegiatan usaha hulu migas yang dilakukan oleh setiap badan usaha dan bentuk usaha tetap yang menjadi kontraktor KKS di setiap wilayah kerja (Didik S. Setyadi, 2007:39). Salah satu bentuk dari pengawasan dan juga pengendalian yang mana dilakukan oleh SKK Migas melalui KKS lainnya ialah SKK Migas mempunyai kewenangan dalam penandatanganan perjanjian lainnya yang mana masih memiliki keterkaitan dalam KKS tersebut, hal itu dinyatakan dalam ketentuan Pasal 86 ayat 5 dan 6 PP No. 35 Tahun 2004 jo. PP No. 34 Tahun 2005 jo. Pasal 1 Perpres No. 95 Tahun 2012 jo. Pasal 1 dan Pasal 2 ayat 1 Perpres No. 9 Tahun 2013.

Selain itu SKK Migas juga mempunyai beberapa tugas yang diatur dalam ketentuan Pasal 90 PP No. 35 Tahun 2004 jo. PP No. 34 Tahun 2005 jo. Pasal 1 Perpres No. 95 Tahun 2012 jo. Pasal 1 dan Pasal 2 ayat 1 Perpres No. 9 Tahun 2013: 1. Memberikan pertimbangan pada menteri atas kebijakannya dalam hal penyiapan, penawaran wilayah kerja serta KKS; 2. Melaksanakan penandatanganan KKS; 3. Mengkaji dan menyampaikan rencana pengembangan lapangan yang pertamakali akan diproduksikan dalam suatu wilayah kerja kepada menteri untuk mendapatkan persetujuan; 4. Memberikan persetujuan rencana pengembangan lapangan sebagaimana yang dimaksud dalam huruf c; 5. Memberikan persetujuan rencana kerja dan anggaran; 6. Melaksanakan monitoring dan melaporkan kepada menteri mengenai pelaksanaan KKS; 7. Menunjuk penjual migas bagian negara yang dapat memberikan keuntungan besar bagi negara. 
Bilamana jika diperhatikan, salah satu tugas yang diemban sebelumnya oleh BP Migas dan yang kini dilanjutkan oleh SKK Migas adalah melaksanakan penandatanganan KKS. Dengan pemahaman bahwa segala bentuk fungsi, tugas, dan juga tanggungjawab pengawasan dan pengelolaan migas yang sebelumnya melekat pada BP Migas kini melekat pada SKK Migas berdasarkan Perpres No. 95 Tahun 2012 dan Perpres No. 9 Tahun 2013 maka SKK Migas berwenang dalam hal menandatangani KKS dengan kontraktor migas. Itulah sebabnya mengapa pemahaman ini linier dengan konsekuensi yuridis formal bahwa dengan bubarnya BP Migas itu tidak menyebabkan batalnya KKS sebab peran BP Migas dengan seluruh fungsi, tugas, wewenang, hak dan kewajiban yang timbul dari KKS, termasuk pula akibat hukum yang dihasilkan dari peristiwa penandatanganan oleh BP Migas terhadap KKS, dialihkan secara serentak dan menyeluruh kepada SKK Migas tanpa ada satu pun reduksi wewenang, hak, dan kewajiban.

\section{Hak Imunitas Pemerintah}

Sebagai pemenuhan akan kebutuhan pelayanan publik, pemerintah dapat dituntut untuk memenuhi kebutuhan tersebut secara permanen dan rutin demi kesejahteraan rakyat. Adapun cara yang dilakukan oleh pemerintah dalam memenuhi kebutuhan yang dimaksud adalah seperti halnya dengan individu, yakni dengan melakukan suatu hubungan kontraktual dengan pihak lain.

Instrumen hukum kontrak menjadi koridor hukum yang sangat penting sebagai upaya perlindungan hukum terhadap aset negara. Urgensi Kontrak Kerja Sama (KKS) sebagai upaya perlindungan hukum terhadap aset negara yang akan dibahas lebih lanjut pada bab selanjutnya. Kontrak tersebut merupakan aturan main (rule of the game) bagi para pihak yang bertindak sebagai kontraktan. Di dalam kontrakkontrak yang melibatkan pemerintah sebagai salahsatu kontraktannya, maka karakteristik kontrak tersebut tidak sepenuhnya tunduk pada hukum privat.

Salah satu aspek terpenting dalam kontrak yang melibatkan pemerintah adalah menyangkut imunitas (kekebalan) pemerintah manakala digugat di muka pengadilan. Demi melindungi aset keuangan negara terdapat peraturan yang juga berfungsi sebagai upaya untuk melindungi kekayaan negara. Pengaturan ini terdapat di dalam Pasal 50 Undang-Undang No. 1 Tahun 2004 tentang Perbendaharaan Negara yang menyebutkan:

Urgensi diterbitkannya aturan tersebut tidak lain adalah sebagai landasan hukum bagi pengelolaan keuangan negara. Prinsip larangan sita yang mana terkandung di dalam Pasal 50 tersebut merupakan penyimpangan dari prinsip sita sebagaimana yang tercantum dalam Pasal 1131 jo. 1132 BW. Implikasi larangan sita atas aset negara dalam kaitan dengan kontrak pemerintah yang dibuat dan tunduk pada hukum Indonesia itu membawa konsekuensi bahwa pemerintah itu kebal atas tuntutan di muka hakim. Konsekuensi kekebalan dimaksud juga tetap mengikat meskipun terdapat suatu klausula yang menyatakan pelepasan terhadap aset negara dan juga sepenuhnya tunduk pada hukum privat (Y. Sogar Simamora, 2009: 103). Pada prinsipnya apabila negara ingin melakukan hubungan kontraktual dengan pihak lain yakni negara tidak boleh sampai dirugikan. Prinsip ini juga berlaku secara universal demi melindungi aset negara.

\section{Production Sharing Contract sebagai Instrumen Perlindungan terhadap Kekayaan Negara Berupa Minyak dan Gas Bumi}

Sebagaimana yang telah disinggung pada uraian sebelumnya, bahwa kontrak pemerintah mempunyai karakteristik berbeda dengan kontrak yang dibuat secara umum antara subjek hukum privat dikarenakan terdapat unsur publik. Seringkali peran pemerintah sebagai double role yakni sebagai subjek hukum publik dan subjek hukum privat, banyak menimbulkan permasalahan khususnya yaitu manakala pemerintah melakukan kontraktualisasi. Kontrak yang dibuat oleh pemerintah tersebut pada dasarnya merupakan kategori perbuatan hukum privat. Hubungan hukum yang lahir merupakan hubungan hukum yang lahir dalam lapangan hukum perdata meskipun di dalam kontrak pemerintah ini berlaku juga syarat-syarat khusus hukum publik dalam pembentukannya (Y. Sogar Simamora, 2009:91). Prinsip hukum yang penting untuk kemudian diperhatikan dalam kontrak yang melibatkan pihak pemerintah sebagai kontraktan adalah; Pertama, kewenangan pejabat dalam membuat dan juga menandatangani kontrak baik pemenuhan terhadap prosedur dan tanggung gugatnya. Kedua, hubungan hukum yang lahir merupakan hubungan hukum perdata dan oleh karenanya jenis kontrak ini sepenuhnya tunduk pada prinsip dan norma hukum kontrak dalam BW. Ketiga, kedudukan pemerintah sebagai kontraktan membawa kosekuensi adanya larangan sita (Y. Sogar Simamora, 2009:105).

\section{Karakteristik Production Sharing Contract}

Kegiatan usaha minyak dan gas bumi ini terdiri atas kegiatan usaha hulu dan kegiatan usaha hilir (UU Migas, Pasal 5). Cakupan kegiatan usaha hulu 
adalah kegiatan eksplorasi dan eksploitasi, sedangkan cakupan kegiatan usaha hilir meliputi pengolahan, pengangkutan, penyimpanan, dan niaga (UU Migas, Pasal 5).

Berdasarkan ketentuan Pasal 6 UU Migas bahwa kegiatan usaha hulu dilaksanakan melalui Kontrak Kerja Sama sebagaimana dimaksud dalam Pasal 1 angka 19 UU Migas. Adapun pengertian Kontrak Kerja Sama berdasar Pasal 1 angka 19 UU Migas adalah Kontrak Bagi Hasil atau bentuk kerjasama lain dalam kegiatan eksplorasi dan eksploitasi yang lebih menguntungkan negara dan hasilnya dipergunakan untuk sebesar-besarnya kemakmuran rakyat. Dalam UU Migas tidak disebutkan pengertian mengenai Kontrak Bagi Hasil (Production Sharing Contract), dus hanya menyebutkan bahwa Production Sharing Contract merupakan salahsatu bentuk dari Kontrak Kerja Sama dalam hal kegiatan usaha hulu minyak dan gas bumi. Namun ketentuan Pasal 1 angka 4 Peraturan Pemerintah No. 35 Tahun 2004 tentang Kegiatan Usaha Hulu Minyak dan Gas Bumi memuat pengertian mengenai Kontrak Bagi Hasil yaitu, suatu bentuk kontrak kerjasama di dalam kegiatan usaha hulu berdasarkan prinsip pembagian hasil produksi. Dengan demikian, Kontrak Bagi Hasil (Production Sharing Contract) itu merupakan instrumen yang digunakan oleh pemerintah dalam penyelenggaraan kegiatan usaha minyak dan gas bumi, khususnya kegiatan usaha hulu.

Kontrak Bagi Hasil merupakan sebuah government contract yang artinya bahwa pemerintah merupakan subjek dalam kontrak (Y. Sogar Simamora, 2009: 55), dan merupakan sebuah regulated contract, yaitu bahwa telah ditentukan mengenai klausula-klausula yang harus ada dalam Kontrak Bagi Hasil. Pengaturan mengenai klausul yang harus ada dalam Kontrak Bagi Hasil terdapat dalam UU Migas, Peraturan Pemerintah No. 42 Tahun 2002 tentang Badan Pelaksana Kegiatan Usaha Hulu Minyak dan Gas Bumi (PP BP Migas) jo. Perpres No. 95 Tahun 2012 jo. Perpres No. 9 Tahun 2013, dan Peraturan Pemerintah No. 35 Tahun 2004 tentang Kegiatan Usaha Hulu Minyak dan Gas Bumi (PP Kegiatan Usaha Hulu Migas) jo. PP (Peraturan Pemerintah) No. 34 Tahun 2005 tentang Perubahan atas Peraturan Pemerintah No. 35 Tahun 2004.

Dalam Kontrak Bagi Hasil, pemerintah sebagai pemegang kuasa pertambangan membentuk SKK Migas untuk melakukan pengendalian Kegiatan Usaha Hulu di bidang minyak dan gas bumi (UU Migas, Pasal 4). SKK Migas adalah suatu unit satuan kerja di bawah naungan Menteri ESDM yang menggantikan fungsi BP Migas yang mana diberi wewenang untuk melaksanakan pengendalian dan pengawasan terhadap pelaksanaan kontrak kerjasama (Didik S. Setiyadi, 2007:38). Dalam hal ini SKK Migas mempunyai tugas utama untuk menandatangani dan melakukan pengawasan dan pengendalian pelaksanaan Kontrak Bagi Hasil dengan Badan Usaha dan Badan Usaha Tetap dalam satu wilayah kerja (PP No. 42 Tahun 2002, Pasal 15).

Sebagai sebuah perjanjian untuk mengambil dan mengelola kekayaan negara, UU Migas mengatur bahwa diharuskan setiap Kontrak Kerja Sama yang telah ditandatangani itu harus diberitahukan secara tertulis kepada Dewan Perwakilan Rakyat Repulik Indonesia (DPR-RI) (UU Migas, Pasal 11 ayat 2). Pemberitahuan ini merupakan wujud dari partisipasi rakyat dalam pengendalian kegiatan eksplorasi dan eksploitasi migas oleh pemerintah sebagai pemegang kuasa pertambangan. Namun partisipasi rakyat secara langsung tersebut relatif kecil karena DPR hanya dapat melakukan fungsi pengawasan pasca Kontrak Kerja Sama ditandatangani namun tidak terlibat dalam proses awal sampai tahap penandatanganan.

Lawan kontrak dari SKK Migas dalam Kontrak Bagi Hasil disebut Badan Usaha dan Badan Usaha Tetap. Pengertian Badan Usaha adalah perusahaan berbentuk badan hukum yang menjalankan jenis usaha bersifat tetap, terus-menerus dan didirikan sesuai dengan peraturan perundang-undangan yang berlaku serta bekerja dan juga berkedudukan dalam wilayah Negara Kesatuan Republik Indonesia (UU Migas, Pasal 1 angka 17). Badan Usaha dalam hal ini bisa berwujud Badan Usaha Milik Negara, Badan Usaha Milik Daerah, Koperasi/usaha kecil, atau pun Badan Usaha Swasta (UU Migas, Pasal 9). Sedangkan pengertian Badan Usaha Tetap adalah badan usaha yang didirikan dan berbadan hukum di luar wilayah Negara Kesatuan Republik Indonesia yang melakukan kegiatan di wilayah Negara Kesatuan Indonesia dan wajib mematuhi peraturan perundang-undangan yang berlaku di Republik Indonesia (UU Migas, Pasal 1 angka 18). Dalam Production Sharing Contract ini, setiap Badan Usaha atau Badan Usaha Tetap hanya diberikan satu wilayah kerja (UU Migas, Pasal 3 ayat 1). Namun jika Badan Usaha atau Badan Usaha Tetap mengusahakan beberapa wilayah kerja, maka UU Migas mensyaratkan agar dibentuk badan hukum yang terpisah untuk setiap wilayah kerja (UU Migas, Pasal 13 ayat 2).

Kontrak Bagi Hasil memiliki jangka waktu selama 30 tahun (UU Migas, Pasal 14 ayat 1) (terdiri atas jangka waktu eksplorasi dan jangka waktu eksploitasi) (UU Migas, Pasal 15 ayat 1) dan dapat diperpanjang 
dengan jangka waktu perpanjangan paling lama 20 tahun untuk setiap perpanjangan (UU Migas, Pasal 14 ayat 2) (jangka waktu untuk kegiatan eksplorasi adalah selama 6 tahun, dan dapat diperpanjang hanya satu kali paling lama 4 tahun berdasarkan permintaan dari kontraktor selama kontraktor telah memenuhi kewajiban minimun menurut Kontrak Kerja Sama yang persetujuannya dilakukan oleh SKK Migas) (PP No. 35 Tahun 2004, dalam Pasal 27). Permohonan akan perpanjangan kontrak tersebut diajukan oleh kontraktor terhadap Menteri ESDM melalui SKK Migas (PP No. 35 Tahun 2004, Pasal 28 ayat 3) SKK Migas berperan dalam mengevaluasi permohonan perpanjangan kontrak sebagai bahan pertimbangan Menteri ESDM dalam memberikan persetujuan atau penolakan (PP No. 35 Tahun 2004, Pasal 28 ayat 4), halmana pertimbangan-pertimbangan tersebut antara lain mengenai potensi cadangan minyak dan/atau gas bumi dari wilayah kerja yang bersangkutan, potensi atau kepastian pasar atau kebutuhan, dan kelayakan teknis atau ekonomis. Permohonan perpanjangan kontrak dapat disampaikan paling cepat 10 tahun dan paling lambat 2 tahun sebelum kontrak berakhir (PP No. 35 Tahun 2004, Pasal 28 ayat 5), namun dalam hal kontraktor telah terikat dengan kesepakatan jual beli gas bumi, kontraktor dapat mengajukan perpanjangan kontrak lebih cepat dari batas waktu (PP No. 35 Tahun 2004, Pasal 28 ayat 6).

\section{Hak dan Kewajiban Para Pihak}

Kontrak bagi hasil berkarakter apa yang menjadi hak bagi kontraktor itu adalah kewajiban dari SKK Migas, begitupun sebaliknya, apa yang menjadi hak dari SKK Migas merupakan sebuah kewajiban bagi pihak kontraktor. UU Migas mengatur mengenai klausul hak dan kewajiban para pihak yang wajib ada dalam Kontrak Kerja Sama, yaitu (UU Migas, Pasal 11): Penerimaan negara; Wilayah kerja dan pengembaliannya; Kewajiban pengeluaran dana; Perpindahan akan kepemilikan hasil produksi atas minyak dan gas bumi; Jangka waktu dan juga kondisi perpanjangan kontrak; Penyelesaian perselisihan; Kewajiban pemasokan minyak dan/atau gas bumi untuk kebutuhan dalam negeri; Berakhirnya kontrak; Kewajiban pascaoperasi pertambangan; Keselamatan dan juga kesehatan kerja; Pengelolaan lingkungan hidup; Pengalihan hak dan kewajiban; Pelaporan yang diperlukan; Rencana pengembangan lapangan; Pengutamaan pemanfaatan barang dan jasa dalam negeri; Pengembangan masyarakat sekitarnya dan jaminan hak-hak dari masyarakat adat; Pengutamaan penggunaan Tenaga Kerja Indonesia.
Salim H.S. mengatakan kewajiban kontraktor menurut ketentuan section V Production Sharing Contract itu antara lain (Salim H.S., 2004:346): 1. Menyediakan semua biaya yang diperlukan untuk membeli atau menyewa peralatan dan juga material; 2. Menyediakan segala bantuan teknis, termasuk tenaga kerja asing; 3. Menyediakan biaya lain untuk pelaksanaan program kerja termasuk pembayaran kepada pihak ketiga (asing) yang mana memberikan jasa kepada kontraktor; 4. Bertanggungjawab atas persiapan dan pelaksanaan program kerja yang akan dilakukan dengan cepat dan dengan menggunakan metode ilmiah; 5. Melakukan peninjauan tentang kondisi lingkungan pada awal kegiatan; 6. Mengambil tindakan-tindakan pencegahan untuk melindungi sistem ekologi, pelayaran, penangkapan ikan dan juga mencegah meluasnya dampak pencemaran laut, sungai-sungai, dan lain-lain, sebagai akibat langsung dari pelaksanaan operasi; 7. Mengeluarkan semua peralatan yang digunakan dari wilayah kontrak sesuai ketentuan SKK Migas dan Pemerintah Indonesia. Alat ini baru dikeluarkan setelah masa kontrak berakhir; 8. Melakukan pemulihan semua lokasi pengeboran sesuai dengan Peraturan Pemerintah, yang bertujuan untuk mencegah risiko terhadap kehidupan manusia dan harta benda atau lingkungan; 9. Memasukkan anggaran tahunan biaya operasional, taksiran biaya pemulihan dan pembebasan lokasi untuk setiap sumur eksplorasi dalam program kerja. Semua biaya yang dikeluarkan oleh kontraktor dalam proses pembebasan sumur-sumur tersebut dan juga pemulihan lokasi pengeboran akan dibayar sebagai biaya operasional; 10. Memasukkan rencana konstruksi untuk setiap penemuan secara komersial, program pemulihan dan pembebasan lokasi bersama sesuai dengan prosedur pendanaan setiap program; 11. Menyerahkan semua salinan data geologi, geofisika, pengeboran, sumur minyak dan produksi dan juga data lainnya kepada Pemerintah Indonesia melalui SKK Migas. Kontraktor dapat memegang salinan data asli yang harus disetujui oleh Pemerintah Indonesia; 12. Menyiapkan dan melaksanakan rencana-rencana dan program-program untuk pelatihan di bidang industri dan pendidikan di Indonesia bagi semua kelompok kerja; 13. Menyetujui penjualan dan pengiriman sejumlah minyak kepada Pemerintah Indonesia yaitu sebanyak $25 \%$ dari total bagi hasil yang diterima kontraktor, penjualan ini baru dilakukan setelah produksi secara komersial; 14. Menggunakan barang-barang dan juga jasa yang diproduksi di Indonesia atau yang dibuat oleh orang Indonesia; 15. Membayar pajak pendapatan kepada Pemerintah Indonesia, termasuk pajak akhir dari 
keuntungan yang diperoleh kontraktor; 16. Menaati semua peraturan yang mana berlaku di Indonesia; 17. Tidak dibenarkan untuk mengungkapkan pada pihak ketiga tentang data geologi, geofisika, petrofisika, teknis, sumur minyak, dan data lainnya tanpa izin tertulis dari Pemerintah Indonesia; 18. Kontraktor akan memberikan dana minimum sebesar 75.000 ribu dolar Amerika sebelum program kerja tahunan dimulai kepada SKK Migas.

Sedangkan hak kontraktor dalam model kontrak Production Sharing Contract yang disajikan oleh Salim H.S., yaitu: 1. Menjual, memberikan, atau memindahkan semua atau sebagian dari hak dan wewenang menurut kontrak pada perusahaan cabang dengan syarat harus ada izin tertulis dari SKK Migas; 2. Menjual, memberikan, atau memindahkan semua atau sebagian hak-hak dan wewenang-wewenangnya menurut kontrak ini kepada pihak-pihak ketiga selain perusahaan cabang dengan izin tertulis dari SKK Migas juga Pemerintah Indonesia; 3. Melakukan pengawasan terhadap semua alat-alat yang disewa; 4. Memasukkan dan juga mengeluarkan fasilitasfasilitas dari suatu wilayah kontrak; 5. Menggunakan dan mengakses semua data dan informasi geologi, geofisika, pengeboran, sumur minyak dan produksi pada wilayah kontrak yang dilakukan oleh Pemerintah Indonesia. Semua biaya untuk mendapatkan data dan informasi tersebut akan disediakan oleh kontraktor, dan juga termasuk biaya operasional; 6. Menjual dan mengekspor minyak mentahnya ke luar negeri; 7. Menunjuk perwakilannya di Jakarta (Salim H.S., 2004:348).

Kewajiban dari SKK Migas sesuai dari Section $V$ model kontrak bagi hasil, yaitu: 1 . Bertanggungjawab kepada manajemen operasional; 2. Membantu dan memperlancar pelaksanaan program kerja kontraktor dengan cara menyediakan fasilitas, pegawai, dan persediaan, tidak terbatas hanya pada penyediaan atau pembuatan visa, izin kerja, transportasi, perlindungan keamanan, dan hiburan yang mungkin diminta pihak kontraktor, dimana biaya untuk menyediakan hal itu akan ditanggung kontraktor sebagai operasional; 3 . Membebaskan kontraktor dari pajak-pajak lain, seperti PPN, Pajak Pemindahan, Pajak Ekspor Impor bahan baku, dan juga peralatan yang dibawa ke Indonesia; 4. Tidak diperkenankan untuk menyampaikan kepada pihak ketiga bahwa semua data asli pengeboran minyak, seperti data geologi, geofisika, petrofisika, teknis, dan data lainnya tanpa izin tertulis dari pihak kontraktor; 5. Menyetujui penggunaan aset oleh pihak ketiga dengan syarat ada izin tertulis dari kontraktor (Salim H.S., 2004:349).
Sedangkan hak dari SKK Migas adalah (Salim H.S., 2004:350): 1. Menerima hasil produksi minyak dan gas bumi, sesuai yang telah ditetapkan antara SKK Migas dengan kontraktor; 2. Menerima pajak pendapatan dan pajak akhir tahun dari kontraktor.

Adapun juga secara umum bahwa hak pembayaran yang diterima oleh negara (melalui SKK Migas) dari KKS adalah sebagai berikut (H. Salim H.S., 2004:293): 1. Pembayaran pajak yang merupakan penerimaan negara; dan 2. Pembayaran bukan pajak yang merupakan penerimaan negara.

Penerimaan negara yang berupa pajak, terdiri atas: 1. pajak-pajak; 2. bea masuk, dan pungutan lain atas impor dan cukai; 3. pajak daerah dan distribusi daerah. Penerimaan negara bukan pajak, terdiri atas: 1 . bagian negara, yaitu bagian produksi yang diserahkan oleh badan usaha atau usaha tetap kepada negara sebagai pemilik sumber daya minyak dan gas bumi; 2. iuran tetap, yaitu iuran yang dibayar oleh badan usaha atau badan usaha tetap kepada negara sebagai pemilik sumber daya minyak dan gas bumi sesuai luas wilayah kerja sebagai imbalan atas kesempatan untuk melakukan kegiatan eksplorasi dan eksploitasi; 3. iuran eksplorasi dan eksploitasi, yaitu iuran yang dibayarkan oleh badan usaha atau badan usaha tetap kepada negara sebagai kompensasi atas pengambilan kekayaan alam minyak dan juga gas bumi yang tak terbarukan; 4. bonus-bonus, yaitu penerimaan dari bonus-bonus penandatanganan. Bonus kompensasi data, bonus produksi dan bonus-bonus dalam bentuk apapun yang diperoleh SKK Migas dalam rangka kontrak Production Sharing.

\section{Klausula-Klausula yang Sifatnya Melindungi Aset Kekayaan Negara}

Isi Kontrak itu merupakan apa yang disepakati oleh para pihak yang dituangkan dalam klausula. Klausula kontrak pada prinsipnya terbagi ke dalam dua kelompok, yaitu Klausula Pokok dan Klausula Penunjang. Klausula Pokok merupakan klausula yang mengatur unsur yang esensial dalam suatu kontrak. Klausula pokok ini mencerminkan jenis kontraknya. Klausula pokok lebih lanjut dapat dikembangkan lebih detail tergantung kesepakatan para pihak. Klausula Penunjang yang mana lazim disebut dengan technical housekeeping clause, itu merupakan klausula yang menunjang atau melengkapi klausula pokoknya. Jika klausula pokok antara satu jenis kontrak dengan jenis kontrak yang lain berbeda, maka klausula penunjang pada umumnya dijumpai dalam kebanyakan kontrak. Klausula ini pada umumnya ada pada setiap jenis kontrak (Y. Sogar Simamora, 2009:289-290). 
Dalam menyusun outline untuk kontrak, maka diperlukanlah pedoman, yaitu: Sistematis, lengkap dan jelas; One clause, one concept; Setiap klausula (pasal) harus diberi judul; Terapkan Prinsip "3P's" (Predict, Provide, dan Protect); Klausula penunjang ditempatkan di bagian akhir. Mengenai Prinsip 3P's itu dapat diterapkan pada saat proses perancangan kontrak. Seorang Contract Drafter harus memegang Prinsip 3P di atas agar kontrak yang mana dibuat itu meminimalisir risiko terhindar dari perselisihan. Klausula yang akan dituangkan di dalam kontrak harus dapat mengakomodasi prinsip antara lain: 1 . Memprediksi atau memikirkan perselisihan apa saja yang akan terjadi; 2. Menyediakan atau mengatur; 3. Melindungi para pihak (Scott J. Burnham, 1993:2).

\section{Prinsip 3 P "Predict"}

Klasula-klausula ini adalah suatu contoh daripada Prinsip Predict.

Pertama, Relinquishment of areas. Klausula ini memuat mengenai syarat dan ketentuan pengembalian wilayah kerja yang dieksploitasi oleh kontraktor. Hal ini juga sejalan dengan ketentuan Pasal 16 UU Migas bahwa badan usaha atau bentuk usaha tetap wajib mengembalikan sebagian wilayah kerjanya secara bertahap atau seluruhnya kepada Menteri.

Kedua, Valuation of crude oil and natural gas. Hasil dari eksploitasi yang berupa minyak dan/atau gas bumi akan dinilai dengan Net Realized Price FOB Indonesia. Hal ini untuk menjaga harga minyak dan/atau gas bumi milik negara yang telah dihasilkan oleh kontraktor.

Ketiga, Termination. Dalam klausula termination, sebuah Kontrak Bagi Hasil tidak bisa diakhiri selama 3 tahun pertama sejak effective date. Namun setelah 3 tahun, jika wilayah tersebut ternyata tidak berpotensi maka kontraktor berhak untuk meminta pengakhiran kontrak. Selain itu jika dalam jangka waktu kontrak, kontraktor tidak bisa melakukan apa yang menjadi kewajibannya, maka BP Migas berhak untuk memutus kontrak agar kemudian wilayah kerja tersebut bisa dikelola oleh pihak kontraktor lainnya. Hal ini guna mengoptimalkan hasil minyak dan gas bumi dalam sebuah wilayah kerja.

Keempat, Consultation and Arbitration. Melihat karakter dari para pihak yang berkontrak, kontrak internasional dapat digolongkan ke dalam empat bentuk sebagai berikut: 1 . antara pihak perusahaan dengan pihak perusahaan asing; 2. antara negara dengan perusahaan asing; 3 . antara sesama pihak negara; 4. antara organisasi internasional dengan pihak perusahaan.
Dalam hal kontrak internasional antara negara dengan perusahaan asing sebagai Kontraktor, dalam Kontrak Production Sharing, terdapat dua subjek hukum dengan kapasitas yang cukup berbeda. Negara adalah subjek hukum yang sempurna dan mempunyai kekuasaan untuk membuat dan melaksanakan hukum serta mengubah hukum. Kedudukan yang mana tidak seimbang ini akan berdampak pada kedudukan hukum para pihak, masalah hukum yang berlaku, dan masalah penyelesaian sengketa.

Dalam Kontrak Production Sharing yang mana dijadikan obyek penelitian ini menggunakan Klausula Penyelesaian Sengketanya dengan menggunakan Penyelesaian Sengketa Alternatif yaitu Arbitrase. Para pihak di dalam Pasal 11 menyebutkan bahwa segala perselisihan yang mungkin terjadi itu diselesaikan terlebih dahulu dengan menempuh jalan musyawarah, baru kemudian bilamana masih terjadi perbedaan interpretasi dan juga pelaksanaan yang kurang tepat dalam melaksanakan klausula yang ada di dalam kontrak, serta tidak dapat diselesaikan maka dapat diselesaikan menggunakan proses arbitrase. Sifat putusan dari arbitrase adalah final dan tidak dapat dilakukan lagi upaya hukumnya dalam hal keberatan dalam sidang arbitrase pertamakali

Klausula mengenai proses penyelesaian sengketa ini merupakan suatu implementasi daripada Klausula yang harus diprediksi. Prinsip 3P yang ketiga yaitu Prinsip Predict. Penyelesaian sengketa diselesaikan melalui forum arbitrase dengan tiga arbiter dengan menggunakan International Chamber of Commerce (ICC), setelah para pihak gagal mencapai kesepakatan dengan musyawarah. Tercantum dalam section $11 \mathrm{di}$ dalam butir ke-5.

\section{Prinsip 3 P "Provide"}

Klausula dalam section 6 ini merupakan salah satu implementasi Prinsip 3P yang Provide, artinya dapat dilihat bahwa di dalam Kontrak Production Sharing diatur mengenai batasan-batasan mengenai biaya di dalam kegiatan dan penanganan kegiatan eksplorasi dan kegiatan eksploitasi yang dilakukan oleh kontraktor.

Pertama, Terms and commerciality of contract area. Sebagai sebuah kontrak untuk mengelola sebuah wilayah yang memiliki potensi minyak dan gas bumi, klausula terms merupakan sebuah klausula preventif. Karena pada hakikatnya, wilayah tersebut adalah milik negara, dan pemerintah adalah sebagai pemegang kuasa untuk mengelola bersama kontraktor.

Kedua, Section 6 Recovery of Operating Cost and Handling of Production. Adanya imbalan atas 
kewajiban-kewajiban, yaitu hak-hak yang diberikan kepada kontraktor termasuk hak untuk mendapatkan kembali (cost recovery) dan pembagian keuntungan serta hak untuk menjual, memindahkan dan juga melepaskan semua atau sebagian dari kewajiban dan haknya kepada afiliasinya atau pihak ketiga. Bersamaan dengan klausul manajemen, pengembalian biaya dan juga pembagian hasil keuntungan berupa produksi merupakan jiwa dari Kontrak Production Sharing. Tata cara klaim pengembalian dijabarkan cukup rinci dalam naskah kontrak, termasuk tata pembukuan dan klasifikasi biaya dan jumlah yang dapat diklaim setiap tahun. Kontraktor mendapatkan penggantian atas biaya kapital dan operasional yang telah dibelanjakan dalam bentuk produksi.

Mengenai klausula cost recovery ini, pada sejak tahun 2005 muncul wacana bahwa sejalan dengan menurunnya produksi minyak dan meningkatnya harga minyak dan adanya penggelembungan biaya untuk pemulihan (cost recovery). Berdasarkan data menunjukkan bahwa meskipun produksi minyak cenderung menurun namun kenaikan harga minyak telah meningkatkan produk sekitar hampir dua kali (Madjedi Hasan, 2009:223).

Klausula lain dalam Kontrak Production Sharing Contract ini diatur juga mengenai jangka waktu, wilayah kerja dan terminasi, persyaratan komersial meliputi kewajiban kontraktor membayar bonus, menyiapkan dan melaksanakan rencana kerja dan anggaran dengan kaidah-kaidah teknik yang baik dan juga kelestarian lingkungan dan mengutamakan produk lokal. Jangka waktu kontrak dibagi dalam dua tahapan, yakni tahapan eksplorasi yang berjalan antara 6 sampai dengan 10 tahun dan tahapan produksi yang dimulai pada saat wilayah kerja memperoleh status komersial dan berakhir sampai dengan masa kontrak.

Ketiga, Books and account and audits. Artinya pembukuan, neraca, dan pemeriksaan keuangan resmi diperlukan sebagai acuan dalam operating cost dan juga dalam cost recovery.

\section{Prinsip 3 P "Protect"}

Dalam Kontrak Production Sharing ini, terdapat klausula: Pertama, Section 5 Rights and obligations of the parties. Pelaksanaan kewajiban kontraktual para pihak dalam Kontrak Production Sharing dituangkan dalam satu klausula yakni terdapat dalam section 5 mengenai Hak dan Kewajiban Para Pihak. Kontraktor berkewajiban dalam hal pertanggungjawaban terkait dengan persiapan dan pelaksanaan eksplorasi dan kegiatan eksploitasi yang mana dapat mempengaruhi ekosistem hayati di tempat dimana diadakan kegiatan eksplorasi dan eksploitasi Minyak dan Gas Bumi.

Adanya kewajiban kontraktor yang harus dipenuhi yaitu segera setelah dimulainya produksi komersial kontraktor wajib menyerahkan sebagian keuntungan yang diterimanya berupa produksi minyak yang mana jumlahnya dihitung dengan memperhatikan produksi minyak dan Konsumsi BBM. Seperti yang tercantum dalam Pasal 22 UU Migas.

Wilayah kerja dapat merupakan pilihan kontraktor, yang mana ditawarkan dalam lelang atau bagian dari wilayah yang telah dilepaskan. Luas wilayah kerja umumnya dihubungkan dengan potensi dari geologi (geological prospectivity) yakni makin tinggi potensi wilayah kerja makin kecil. Terkait dengan wilayah kerja ini yaitu kewajiban pihak kontraktor melakukan kegiatan usaha eksplorasi. Dalam jangka waktu untuk melaksanakan kegiatan usaha eksplorasi beragam dari 3 sampai dengan 6 tahun, yang dapat diperpanjang. Usaha eksplorasi merupakan kegiatan yang berisiko dan mahal yang terdiri dari dua atau lebih fase dan dihubungkan dengan komitmen finansial (Madjedi Hasan, 2009:67).

Pelepasan wilayah pada akhir setiap fase eksplorasi dimaksudkan untuk memacu kontraktor mempercepat pelaksanaan kegiatan usaha eksplorasi. Jika berhasil menemukan cadangan yang dapat dikembangkan, maka kontrak dilanjutkan dengan masa eksploitasi yang dapat berjalan sampai dengan 30 tahun.

Kedua, Work program and budget. Artinya bahwa, klausula ini memuat anggaran yang akan dikeluarkan oleh kontraktor. Dalam klausula ini juga disebutkan mengenai sebuah performance bond yang mana wajib dikeluarkan oleh pihak kontraktor.

\section{PENUTUP \\ Kesimpulan}

Bentuk perlindungan hukum terhadap aset negara terkait dengan pengelolaan minyak dan juga gas bumi antara lain: Pertama, Pemerintah memiliki hak imunitas (kekebalan) manakala digugat di muka pengadilan dalam hal mana terjadi penyitaan terhadap aset negara. Hal ini merupakan upaya perlindungan hukum terhadap suatu aset Negara demi terwujudnya pemenuhan akan kebutuhan publik yang digunakan sebesarnya demi kemakmuran rakyat. Hak imunitas dimaksud juga dapat berfungsi sebagai bargaining position bagi negara, sebelum pihak menandatangani Production Sharing Contract. Kedua, yaitu adanya ketentuan mengenai penerimaan negara, pungutan negara, dan bonus yang diimplementasikan dalam ketentuan bagi hasil dalam model kontrak Production 
Sharing Contract. Ketiga, Adanya ketentuan bagi kontraktor untuk mendistribusikan sebagian dari bagi hasil produksi guna pemenuhan kebutuhan minyak dan gas bumi dalam negeri.

Production Sharing Contract ini adalah suatu instrumen pemerintah dalam mengadakan perjanjian pengelolaan Minyak dan Gas Bumi dengan kontraktor, khususnya kegiatan usaha hulu. Dalam UU Migas tidak disebutkan pengertian mengenai Kontrak Bagi Hasil (Production Sharing Contract), dimana hanya menyebutkan bahwa Production Sharing Contract merupakan salahsatu bentuk dari Kontrak Kerja Sama dalam kegiatan usaha hulu minyak dan gas bumi. Sebagai suatu proteksi terhadap pemerintah, di dalam UU Migas telah mengatur mengenai klausula minimal yang harus ada dalam sebuah model kontrak Production Sharing Contract. Klausula-klausula yang terpenting adalah klausula Valuation of crude oil and natural gas, klausula Relinquishment of areas, dan klausula Recovery of Operating Cost and Handling of Production.

\section{Rekomendasi}

Diharapkan pemerintah dapat segera merevisi UU Migas dan mengatur mengenai pengertian Kontrak Bagi Hasil (Production Sharing Contact) supaya ada kejelasan dan tidak terjadi kerancuan tentang definisi Production Sharing Contact tersebut.

\section{DAFTAR PUSTAKA}

Buku:

Atiyah, P.S., 1996, An Introduction to the Law of Contract, New York: Oxford University Press.

Burnham, Scott J., 1993, Drafting Contracts second edition, Virginia: Michie Company.

Hasan, A. Madjedi, 2009, Kontrak Minyak dan Gas Bumi Berazas Keadilan dan Kepastian Hukum, Jakarta: Fikahati Aneska.

Miru, Ahmadi, 2007, Hukum Kontrak dan Perancangan Kontrak, Jakarta: Rajagrafindo Persada.

Muhammad, Abdulkadir, 1990, Hukum Perdata Indonesia, Bandung: Citra Aditya Bakti.
Naja, H. R. Daeng, 2006, Contract Drafting, Edisi Revisi-Cetakan Kedua, Bandung: Citra Aditya Bakti.

Saleng, Abrar, 2004, Hukum Pertambangan, Yogyakarta: UII Press Yogyakarta.

Setyadi, Didik S., 2007, Aspek Hukum Administrasi Eksplorasi dan Eksploitasi Minyak dan Gas Bumi di Indonesia, Surabaya: Nusantara Makmur.

Simamora, Y. Sogar, 2009, Prinsip Hukum Kontrak dalam Pengadaan Barang dan Jasa oleh Pemerintah, Yogyakarta: Laksbang PRESSindo.

Subekti, R., 1979, Aneka Perjanjian, Bandung: Alumni.

\section{Peraturan Perundang-undangan:}

Undang-Undang Dasar Republik Indonesia 1945.

Undang-Undang No. 22 Tahun 2001 tentang Minyak dan Gas Bumi.

Peraturan Pemerintah No. 35 Tahun 2004 tentang Kegiatan Usaha Hulu Minyak dan Gas Bumi.

Peraturan Pemerintah No. 42 tahun 2002 tentang Badan Pelaksana Kegiatan Usaha Hulu Minyak dan Gas Bumi.

Peraturan Presiden No. 95 Tahun 2012 tentang Pengalihan Pelaksanaan Tugas dan Fungsi Kegiatan Usaha Hulu Minyak dan Gas Bumi.

Peraturan Presiden No. 9 Tahun 2013 tentang Penyelenggaraan Pengelolaan Kegiatan Usaha Hulu Minyak dan Gas Bumi.

\section{Putusan:}

Putusan Mahkamah Konstitusi No. 002/PUU-I/ 2003.

Putusan Mahkamah Konstitusi No. 46/PUU-VI/ 2008

Putusan Mahkamah Konstitusi No. 36/PUU-X/ 2012.

\section{Website:}

http://www.hukumonline.com/berita/ baca/1t50a2367d 37 e 5 c/mk--bp-migasinkonstitusional. 